\title{
Graft incompatibility in plants: Metabolic changes during formation and establishment of the rootstock/scion union with emphasis on Prunus species
}

\author{
Felipe Gainza $^{1^{*}}$, Ismael Opazo ${ }^{1}$, and Carlos Muñoz ${ }^{2}$
}

Commercial fruit trees are usually formed by the combination of a rootstock and a scion to broaden the adaptability of scion cultivars to soil and climatic conditions, facilitate agricultural management, and/or increase productivity. In the different cultivated species of the genus Prunus, rootstocks having a wide range of uses are scarce, because of rootstock/ scion graft incompatibilities that prevent the establishment of a strong and lasting functional union. Graft incompatibility is a problem in cherry, almond, and apricot than in peach or plum. In general, closely related cultivars and species tend to be compatible, but taxonomically distant plants often manifest incompatibility. This review will focus on the knowledge currently available on the metabolic response during the formation and establishment of the stock/scion graft union in order to help the effort for identify future metabolic markers to be used in breeding programs. The physiological, metabolic and molecular mechanisms that cause incompatibility remain unclear and several hypotheses have been proposed to explain it, mostly based on herbaceous species. Few studies are available to explain incompatibility in woody plants. Various phenolic compounds are known to affect cell division, development and differentiation at the graft union. Flavonol (catechins and proanthocyanidins) concentrations increase shortly after grafting and, as a result of the stress induced during the healing response, vacuolar membrane disruption occurs resulting in the escape of phenols from the vacuole into the cytoplasmic matrix, causing dysfunctions in the growth of certain tissues (xylem and phloem), interference with the synthesis of lignin or inducing hormonal imbalances. All these abnormalities result in mechanical weakening of the union, which may manifest during the first year after grafting (translocated incompatibility) or may appear several years later (localized incompatibility), leading to major economic losses. More research is needed to fully understand the mechanism of graft incompatibility, particularly in woody plants. This knowledge is essential to develop molecular markers useful in rootstock breeding programs.

Key words: Prunus, interspecific hybrids, localized incompatibility, translocated incompatibility.

\section{INTRODUCTION}

Modern fruit growing makes extensive use of selected rootstocks for a variety of purposes, including vigor control, which enable high density planting, disease and pest tolerance/resistance, resistance/tolerance to abiotic stresses like hypoxia, reduce the time to fruiting, increase profit returns, improve fruit quality and yield, improve cold hardiness, cope with the chilling requirement of the scion, and/or to alleviate certain syndromes like replant complex. In addition, modern cultural methods are evolving towards the use of clonal rootstocks as opposed to seeding rootstocks that were commonly used in the

${ }^{1}$ Centro de Estudios Avanzados en Fruticultura (CEAF), Camino Las Parcelas 882, sector Los Choapinos, Rengo, Chile.

*Corresponding author (fgainza@ceaf.cl).

${ }^{2}$ Universidad de Chile, Facultad de Ciencias Agronómicas, Santa

Rosa 11315, La Pintana, Santiago, Chile.

Received: 17 January 2015.

Accepted: 5 May 2015.

doi: $10.4067 /$ S0718-58392015000300004 past. The above-mentioned role of rootstocks is the result of active rootstock/scion interactions, most of which are the result of complex processes occurring at the rootstock/ scion union, most of which are poorly understood.

The most important of these interactions is compatibility between rootstock and scion. There is rootstock/scion compatibility when a given combination is able to form a solid and durable graft union. Compatibility is difficult to predict, but there is a general consensus that a degree of taxonomic relatedness should exist in order for a particular stock/scion combination to be compatible. The greater the taxonomic distance between stock and scion the smaller the chances of forming a successful graft union. This means that the theoretical success of a particular graft union combination is intraclonal $>$ interclonal $>$ intraspecific $>$ interspecific $>$ intrageneric $>$ intergeneric $>$ intrafamilial (Andrews and Marquez, 1993). Also, different taxa may differ in the degree of relatedness required for the formation of successful graft unions (Rom and Carlson, 1987). Therefore, compatibility is very specific, meaning that a particular rootstock is 
generally not compatible with all commercial varieties of a given species. In modern horticulture this is a limiting factor, particularly in peach and cherry where there is a lack of commercial rootstocks having broad compatibility (Okie, 1987; Zarrouk et al., 2006).

Rootstock/scion graft compatibility is, therefore, a critical issue for orchard performance and longevity. According to Yeoman (1984), compatibility can be regarded as a recognition system in which molecules released from the plasmalemmas combine to form a complex with catalytic activity that subsequently initiates a developmental sequence resulting in the development of a successful graft. To remain functional, the stock/scion union should unify intimately, providing a viable system for the uptake and translocation of minerals, water, assimilates, and hormones throughout the entire lifespan of the plant (Martínez-Ballesta et al., 2010; Gregory et al., 2013; Koepke and Dhingra, 2013). In contrast, graft "incompatibility" leads to unhealthy trees, breakage at the graft union, premature death or failure of the graft combination and incapacity to form a strong and lasting functional union (Zarrouk et al., 2006). In Prunus species, incompatibility is a problem in cherry, almond and, especially, apricot, than in peach or plum (Table 1) (Lang and Ophardt, 2000).

Two types of incompatibility are recognized: so called translocated graft incompatibility and localized graft incompatibility (Herrero, 1951; Mosse, 1962). The former is usually expressed during the first year after grafting as growth cessation, defoliation, and leaf discoloration (Herrero, 1951; Mosse, 1962). In peach/plum combinations, this form of incompatibility has been associated with both biochemical and functional alterations at the graft interface, inducing a carbohydrate blockage at the scion, above the graft union (Moing and Carde, 1988; Moing et al., 1990). In the latter case, incompatibility symptoms occur at a later stage of development (Herrero, 1951; Mosse, 1962), where the presence of some biochemical alterations across the graft union may lead to a slight and delayed incompatibility, as has been described in cherry and peach/plum combinations (Treutter and Feucht, 1991; Salesses and Bonnet, 1992). This type of incompatibility is characterized by anatomical irregularities at the stock/scion union interface, with breaks in vascular and cambial continuity patterns and poor vascular connections that induce mechanical weakness in the union (Errea et al., 2001; Koepke and Dhingra, 2013) that may break out after years of orchard establishment, leading to major economic losses (Herrero, 1951).

Despite the importance of incompatibility for the development of new rootstocks, the physiological and metabolic mechanisms involved in an incompatible response remain unclear (Zarrouk et al., 2006). This lack of understanding is probably due to the lack of adequate methods to analyze the metabolic changes occurring during the development of the stock/ scion union. Only a few studies have been made on compatibility in woody plants (Errea et al., 1994; Errea, 1998; Salvatierra et al., 1998; 1999; Pina and Errea, 2005; Koepke and Dhingra, 2013) and the hypotheses that currently explain the causes of incompatibility have been obtained mainly from studies done in herbaceous plants during the early

Table 1. Rootstock/scion compatibility performance in different Prunus species and some interspecific hybrids.

\begin{tabular}{|c|c|c|c|}
\hline Rootstock type & Pedigree & Compatibility performance & References \\
\hline \multirow[t]{2}{*}{$\begin{array}{l}\text { Japanese plum/peach } \\
\text { Fast-growing plums }\end{array}$} & Prunus salicina $\times$ Prunus persica & $\begin{array}{l}\text { Very good with plums and apricots, but not } \\
\text { with peaches }\end{array}$ & Zaiger, 1982 \\
\hline & $\begin{array}{l}\text { Prunus cerasifera and interspecific } \\
\text { hybrids }\end{array}$ & $\begin{array}{l}\text { Performance differs substantially depending } \\
\text { on the genotype, 'Adara' rootstock confers } \\
\text { compatibility even with cherry cultivars } \\
\text { when it is used as an interstock }\end{array}$ & Zarrouk et al., 2006 \\
\hline Peach & Prunus persica $\times$ Prunus davidiana & $\begin{array}{l}\text { Wide range of compatibility with most peach } \\
\text { and nectarine cultivars }\end{array}$ & $\begin{array}{l}\text { Lang and Ophardt, 2000; } \\
\text { Zarrouk et al., } 2006\end{array}$ \\
\hline Peach/almond & Prunus persica $\times$ Prunus dulcis & $\begin{array}{l}\text { Wide range of compatibility with most peach } \\
\text { and nectarine cultivars }\end{array}$ & $\begin{array}{l}\text { Lang and Ophardt, 2000; } \\
\text { Zarrouk et al., } 2006\end{array}$ \\
\hline Slow-growing prunes & Prunus domestica & $\begin{array}{l}\text { Wide range of compatibility with most peach } \\
\text { and nectarine cultivars }\end{array}$ & $\begin{array}{l}\text { Lang and Ophardt, 2000; Zarrouk et al., } \\
2006\end{array}$ \\
\hline Slow-growing prunes & Prunus insititia & $\begin{array}{l}\text { Wide range of compatibility with most peach } \\
\text { and nectarine cultivars }\end{array}$ & $\begin{array}{l}\text { Lang and Ophardt, 2000; Zarrouk et al., } \\
2006\end{array}$ \\
\hline Cherry & Prunus avium $\times$ Prunus pseudocerasus & $\begin{array}{l}\text { Wide range of compatibility with most sweet } \\
\text { cherry cultivars except 'Sam' and 'Van' }\end{array}$ & Rom and Carlson, 1987 \\
\hline Cherry & Prunus avium & $\begin{array}{l}\text { Incompatible with peach, nectarine and } \\
\text { almond but compatible with all sweet cherry } \\
\text { cultivars }\end{array}$ & Beckman and Lang, 2003 \\
\hline Cherry & Prunus mahaleb & $\begin{array}{l}\text { Incompatible with several sweet cheery } \\
\text { scion cultivars like 'Lapins', 'Chelan' and } \\
\text { 'Tieton' }\end{array}$ & Long and Kaiser, 2010 \\
\hline Cherry & Prunus cerasus & $\begin{array}{l}\text { Incompatible with several sweet cherry scion } \\
\text { cultivars }\end{array}$ & Long and Kaiser, 2010 \\
\hline Cherry & Prunus cerasus $\times$ Prunus canescens & $\begin{array}{l}\text { Wide range of compatibility with most sweet } \\
\text { cherry cultivars }\end{array}$ & Long and Kaiser, 2010 \\
\hline
\end{tabular}


stages of development of the graft union (Tiedemann, 1989; Aloni et al., 2008; Koepke and Dhingra, 2013). Also, to study the integrity of the union, destructive methods are necessary in order to carry out anatomical studies to visualize the integrity and functionality of the connections between the stock and the scion.

This review will focus on the knowledge currently available on the metabolic response during the formation and establishment of the stock/scion graft union in order to help the effort for identify future metabolic markers to be used in breeding programs.

\section{Metabolic pathways}

Recent data demonstrate that several biochemical pathways are affected during graft union formation (Koepke and Dhingra, 2013). One of these is the metabolism of phenolic compounds (Haslam and Lilley, 1986), which are also involved in the stress and wounding response (Leonardi and Romano, 2004; Cohen et al., 2007). As expected in a normal wound reaction, an intense production of new phenolic compounds has been reported during the establishment of a graft union (Tiedemann, 1989; Hartmann et al., 2002; Kueger et al., 2012). In incompatible heterografts, where stock and scion come from different species, quantitative and qualitative diffusion of these compounds through the union can produce metabolic dysfunctions. It is known that small quantities of phenols can be enough to produce locally limited dysfunctions in the interphase between two or more cells (Treutter and Feucht, 1991; Fiehn et al., 2008). Moreover, studies using callus cultures of Prunus avium (L.) L. have shown that the flavin prunin, a typical phenol of Prunus species, interferes with the permeability of the tissues, which results in membrane damage (Harborne, 1994). In addition to prunin, other phenols may participate in transport across cell membranes into the extracellular free space (Salvatierra et al., 1999).

Phenolic compounds have also been associated with the different processes involved in cell division, development, and differentiation (Errea et al., 1992; Elstner et al., 1994). In incompatible graft unions, phenols move from the vacuole into the cytoplasm, causing stress that results in growth dysfunction, probably caused by an inhibition of the lignin pathway (Tiedemann, 1989; Elstner et al., 1994; Hartmann et al., 2002). Also, concentrations of flavonols (catechins and proanthocyanidins) increase under stress and grafting is no exception (Errea et al., 1994; Cooman et al., 1996; Errea, 1998).

Hormones are another important class of compounds implicated in the development of the graft union. For instance, auxins are released from vascular strands of both stock and scion to induce the differentiation of vascular tissues (Aloni, 2010; Aloni et al., 2010;
Koepke and Dhingra, 2013). Auxin translocation from the root system has been studied in apple in relation to graft incompatibility, since a supra and basipetal movement of auxin can affect the morphogenetic pattern of the entire plant body (Treutter and Feucht, 1988; Koepke and Dhingra, 2013).

Phenolic compounds and hormones also interact with each other. Lack of compatibility has been associated with a pronounced accumulation of polyphenols above the graft union (Feucht et al., 1992), which are known to affect auxin transport (Errea et al., 1994; Errea, 1998). Other authors have reported that a low indole-3-acetic acid (IAA) content in incompatible combinations may then affect the differentiation of xylem and phloem, as well as lignification (Pina and Errea, 2005; Aloni et al., 2010; Koepke and Dhingra, 2013). This implication of flavonols at work in stressed unions has also been discussed in terms of a delay in senescence during the beginning of the stress phase. The accumulation of flavonols in graft unions and their degradation by oxidases can have important effects on the growth and metabolism of tissues (Pina and Errea, 2005).

Complex physiological disorders are directly related to the presence, absence or interactions of specific combinations of metabolites (Fiehn, 2000). It is often combinations of metabolites, rather than the presence of individual compounds, that are of biological relevance (Hall, 2006; Hardy and Hall, 2012). In particular, a complex disorder such as incompatibility inevitably has a complex biochemical background and depends on specific genetic interactions between the cells of the stock and the scion (Koepke and Dhingra, 2013). Metabolic interactions are difficult to analyze using traditional methods; however, now using a metabolomic approach it is possible to better understand these complex phenomena. Metabolomic technologies now available allow studies of the biochemical composition of biological materials to be made without having prior metabolic knowledge (Hall, 2006; Hardy and Hall, 2012; Kueger et al., 2012).

\section{Formation of the stock/scion union}

As mentioned before, the success of grafting depends primarily on the compatibility of the graft union to enable rapid development of vascular connections between the stock and the scion (Olmstead et al., 2006), which, in turn, will allow quick resumption of the growth of both the root and the canopy (Hartmann et al., 2002; Leonardi and Romano, 2004; Cohen et al., 2007). In grafted plants, vascular regeneration is a complex process that includes structural differentiation of the parenchymatous tissue from both sides of the graft union into xylem and phloem (Olmstead et al., 2006; Aloni et al., 2010). The sequence of structural events occurring during the healing of the graft union 
in woody and herbaceous plants has been reviewed by several authors (Moing and Carde, 1988; Tiedemann, 1989; Hartmann et al., 2002; Pina and Errea, 2005), but recently Yin et al. (2012) identified six major events: (i) Wound-induced response, (ii) cleanup of cell debris, (iii) cellular communication, (iv) auxin accumulation and responses, (v) cell division and differentiation, and (vi) vascular reconnection. It is now known that some mRNA signals change just 24 $\mathrm{h}$ after grafting, and that $48 \mathrm{~h}$ after grafting auxins increase at the union and stimulate cell division and differentiation. On the third day, transport was already functioning across the graft union (Yin et al., 2012; Koepke and Dhingra, 2013). This is an indication that new xylem and phloem formation follow the same pattern described by Dengler (2001) in normal shoots and roots.

\section{Phenolic compounds and their metabolic interactions}

Phenolic compounds are secondary metabolites present in all higher plants (Harborne, 1994) that are involved in a number of metabolic pathways, interacting with the plant environment and with plant pathogens (Errea, 1998; Pina et al., 2011). It is well known that genes encoding for the enzymes of these pathways, like phenylalanine ammonia-lyase (PAL), polyphenol oxidase (PPO), and peroxidases (POD), are developmentally and tissue-specifically regulated and may be induced by environmental stresses (Pina and Errea, 2008). Phenolic compounds, particularly the ortodiphenols, are susceptible to oxidation by proteins coded by these genes, resulting in the production of quinones and polymeric melanins (Errea, 1998). This process and the reduction of cinnamic acids to their corresponding alcohols to produce lignin is a common phenomenon in the plant kingdom.

There is a group of phenolic compounds, flavonols (catechins and proanthocyanidins), that have important roles in woody plants, including the relationships between rootstock and scion (Treutter and Feucht, 1988; Stafford, 1990; Treutter and Feucht, 1991; Harborne, 1994; Errea, 1998; Salvatierra et al., 1999; Usenik et al., 2006; Martínez-Ballesta et al., 2010). trans-Cinnamic acid, a metabolite derived from phenylalanine by the action of PAL, is generally recognized as a marker of environmental stress and a potential site for pathway regulation during the synthesis of flavonoid compounds, xylogenesis, and formation of lignin, one of the main cell wall polymers (Rogers and Campbell, 2004). Pina and Errea (2008) demonstrated for the first time that the level of PAL transcription is enhanced in incompatible Prunus unions, resulting in an accumulation of phenol. In incompatible stock/scion combinations, the cellular system is weakened, resulting in loss of structure of the vacuolar membrane, where flavonols are located, due to lipid peroxidation (Torel et al., 1986). Phenols escape from the vacuole into the cytoplasmic matrix where they are oxidized by peroxidases and phenol oxidases (Hartmann et al., 2002). As a result, ortoquinones are formed, which may polymerize to become toxic compounds in a number of chemical reactions (Poëssel et al., 1980). In turn, these orto-quinones can act as crosslinking agents with nucleophilic groups in proteins and other macromolecules, forming irreversible unions that affect the later development of the lignin pathway (Buchloh, 1961; Haslam and Lilley, 1986), impairing a good connection between the stock and scion (Poëssel et al., 1980; Feucht and Treutter, 1991; Pina and Errea, 2005).

The phenylpropanoid pathway has been identified as one of those responsible for physiological failure in stock-scion combinations where Prunus armeniaca L. is involved (Pina et al., 2011).

\section{The role of hormones}

Endogenous plant hormones are thought to be involved in regulating the complex relationships between rootstock and scion (Sorce et al., 2002; Aloni et al., 2010; Koepke and Dhingra, 2013). In vascular regeneration experiments, when auxins were applied exogenously to stem segments, low concentrations $(0.1 \%, \mathrm{w} / \mathrm{w})$ of indole-3-acetic acid (IAA) stimulated phloem differentiation, whereas higher levels $(1.0 \%$, w/w) induced xylem differentiation (Aloni, 1995; 2001; 2010). Likewise, in grafting experiments, an important group of substance involved in the development of compatible graft unions are the auxins released from the vascular strands of the stock and the scion, which induce the differentiation of vascular tissues, thus functioning as morphogenic substances (Aloni, 1987; Mattsson et al., 2003). Auxin translocation from the scion to the stock were found to accelerate the development of a successful graft union in Cactus (Shimomura and Fujihara, 1977).

Aloni et al. (2008; 2010) showed that, in grafted Cucurbita, exogenous application of high concentrations $\left(\geq 10^{-7} \mathrm{M}\right.$ ) of 1-naphthaleneacetic acid (NAA), a synthetic auxin, to the root caused inhibition of root growth. Root growth of incompatible grafts was more affected than that of compatible ones. NAA was also applied directly to the roots of hydroponically grown grafted plants, which caused root decay in incompatible grafts but less harm in compatible ones. The involvement of auxin in the incompatibility mechanism emerged from three additional observations: (i) endogenous IAA analysis revealed that the roots and stems of incompatible combinations contained higher IAA concentrations than the same tissues of compatible ones; (ii) application of the auxin transport inhibitor, 2,3,5-triiodobenzoic acid, to the stems of grafted plants negated root degradation in incompatible combinations, whereas it had only 
slight effect on compatible graft combinations; and (iii) root and shoot development of incompatible grafts was normal after blocking basipetal IAA transport by partial stem girdling (Aloni et al., 2008). These results support the hypothesis that auxin produced in the scion is translocated downwards to the root after the graft connection is established, where, after reaching a threshold concentration, auxin triggers degradative processes causing root decay (Aloni, 2010; Aloni et al., 2010).

In $P$. tomentosa (stock) and P. armeniaca (scion), a differential accumulation of flavon-3-ols occurring during the early stages of grafting was related to problems in the differentiation of callus (Errea et al., 1994; Salvatierra et al., 1999) and cathechin, a flavonol, is known to be a protective agent against IAA oxidation (Lee and Oda, 2003; Parham and Kaustinen, 1977; Salvatierra et al., 1999) and can modulate the IAA oxidase level (Salvatierra et al., 1999). Moreover, the synthesis of prunasin, another flavon-3-ol, can determine incompatibility in Prunus (Moing and Carde, 1988; Stafford, 1990) and be stimulated by ABA and GA (Treutter and Feucht, 1991; Salvatierra et al., 1999; Aloni et al., 2010). Similarly, in phloem tissues of heterografts, the increase in prunin above the union indicates that the rootstock influences the normal gradient of phenolic compounds (Salvatierra et al., 1999). Feucht et al. (1988) also noticed that prunin caused less callus growth and inhibited xylogenesis and peroxidase activity. In xylem tissue, prunin and naringenin, which accumulated at the graft union of heterograft trees, could affect wound healing. Although less naringenin than prunin was found, this relatively small amount of naringenine may still be enough to induce dysfunction at the interface between two cells (Errea et al., 1994). Naringenin was found to function as an inhibitor of the growth promoting activity of gibberellin while also stimulating IAA oxidase (Feucht et al., 1988).

\section{CONCLUSIONS}

To date, several studies have been performed in order to understand the mechanism of graft incompatibility and yet there are still elements not fully understood. These studies refer to cytological and biochemical responses that occur early in the graft, as well as their consequences for the formation of tissues that lead to vascular connection. However, the vascular connection by itself does not ensure compatibility. Mechanisms such as cell recognition, connections between conductive tissues from rootstocks and scions, the presence of growth regulators and their interactions with others metabolites like phenols or enzymes are still enigmatic. In this way, when compatible and incompatible graft unions in Prunus species are compared, clear differences exist from an early stage of callus differentiation into cambium and vascular tissues, which in compatible unions proceed rapidly. In the other hand, in incompatible unions a large proportion of the callus does not differentiate. The fact that this process could be detected at an early phase of graft development, together with the advantages of new metabolomic approaches to identify metabolic interactions, opens new strategies for the early detection of incompatibility in fruit trees. Moreover, the identification of key genes involved in graft incompatibility, like PAL, offer feasible tools to develop early selection strategies in long term breeding programs. In short, research is continually delivering new insights in this area that will contribute to better explaining the mechanism of graft incompatibility in fruit species, providing new challenges together with new techniques to better understand this phenomenon.

\section{ACKNOWLEDGEMENTS}

We thank the Centro de Estudios Avanzados en Fruticultura (CEAF) and the CONICYT Regional project R08I1001 for financing this review.

\section{LITERATURE CITED}

Aloni, R. 1987. Differentiation of vascular tissues. Annual Review of Plant Physiology 38:179-204.

Aloni, R. 1995. The induction of vascular tissues by auxin and cytokinin. p. 531-546. In P.J. Davies (ed.) Plant hormones. Kluwer Academic Publishers, Dordrecht, The Netherlands.

Aloni, R. 2001. Foliar and axial aspects of vascular differentiationhypothesis and evidence. Journal of Plant Growth Regulation 20:22-24.

Aloni, R. 2010. The induction of vascular tissues by auxin plant hormones. p. 485-518. In P.J. Davies (ed.) Springer, Dordrecht, The Netherlands.

Aloni, R., R. Cohen, L. Karni, H. Aktas, and M. Edelstein. 2010. Hormonal signaling in rootstock-scion interactions. Scientia Horticulturae 127:119-126.

Aloni, B., L. Karni, G. Deveturero, Z. Levin, R. Cohen, N. Kazir, et al. 2008. Physiological and biochemical changes at the rootstock-scion interface in graft combinations between Cucurbita rootstocks and a melon scion. Journal of Horticultural Science and Biotechnology 83:777-783.

Andrews, P.K., and C.S. Marquez. 1993. Graft incompatibility. Horticultural Reviews 15:183-232.

Beckman, T.G., and G.A. Lang. 2003. Rootstock breeding for stone fruits. Acta Horticulturae 622:531-551.

Buchloh, G. 1961. The lignification in stock-scion junctions and its relation to compatibility. In J.B. Pridham (ed.) Phenolics in plants in health and disease. Zeitschrift für Pflanzenernährung, Düngung, Bodenkunde 93(3):247. doi:10.1002/jpln.19610930311.

Cohen, R., Y. Burger, C. Horev, A. Koren, and M. Edelstein. 2007. Introducing grafted cucurbits to modern agriculture: The Israeli experience. Plant Disease 91:916-923.

Cooman, L.D., E. Everaert, P. Curir, and M. Dolci. 1996. The possible role of phenolics in incompatibility expression in Eucalyptus gunni micrografts. Phytochemical Analysis 7:92-96.

Dengler, N.G. 2001. Regulation of vascular development. Journal of Plant Growth Regulation 20:1-13. 
Edelstein, M., Y. Burger, C. Horev, A. Porat, A. Meir, and R. Cohen. 2004. Assessing the effect of genetic and anatomic variation of Cucurbita rootstocks on vigor, survival and yield of grafted melons. Journal of Horticultural Science and Biotechnology 79:370-374

Elstner, E.F., W. Obwald, R. Volpert, and H. Schempp. 1994. Phenolic antioxidants. Acta Horticulturae 381:301-335.

Errea, P. 1998. Implications of phenolic compounds in graft incompatibility in fruit tree species. Scientia Horticulturae 74:195-205

Errea, P., A. Felipe, and M. Herrero. 1994. Graft establishment between compatible and incompatible Prunus spp. Journal of Experimental Botany 45:393-401.

Errea, P., L. Garay, and J.A. Marín. 2001. Early detection of graft incompatibility in apricot (Prunus armeniaca) using in vitro techniques. Physiologia Plantarum 112:135-141.

Errea, P., D. Treutter, and W. Feucht. 1992. Specificity of individual flavan-3-ols interfering with the grafting stress of apricots. Angewandte Botanik 66:21-24.

Feucht, W., and D. Treutter. 1991. Phenol gradients in opposing cells of Prunus heterografts. Advances in Horticultural Science 5:107-111.

Feucht, W., D. Treutter, and E. Christ. 1992. Localization and quantitative determination of catechins and proanthocyanidins in the phloem of elm and cherry. Tree Physiology 10:169-177.

Feucht, W., D. Treutter, and P. Schmid. 1988. Inhibition of growth and xylogenesis and promotion of vacuolation in Prunus callus by the flavanone prunin. Plant Cell Report 7:1898-1192.

Fiehn, O. 2000. Metabolite profiling for plant functional genomics. Nature Biotechnology 18:1157-1161.

Fiehn, O., G. Wohlgemuth, M. Scholz, T. Kind, D.Y. Lee, Y. Lu, et al. 2008. Quality control for plant metabolomics: reporting MSIcompliant studies. The Plant Journal 53:691-704.

Gregory, P.J., C.J. Atkinson, A.G. Bengough, M.A. Else, F. Fernández-Fernández, R.J. Harrison, et al. 2013. Contributions of roots and rootstocks to sustainable, intensified crop production. Journal of Experimental Botany 64:1209-1222.

Hall, R.D. 2006. Plant metabolomics: From holistic hope, to hype, to hot topic. New Phytologist 169:453-468.

Hardy, N.W., and R.D. Hall. 2012. Practical applications of metabolomics in plant biology. p. 1-10. In Plant metabolomics. Methods and protocols. Methods in Molecular Biology 860 . doi:10.1007/978-1-61779-594-7.

Harborne, J.B. 1994. Flavonoids: Advances in research since 1986. Chapman and Hall, London, UK.

Hartmann, H.T., D.E. Kesler, F.T. Davies, and R.L. Geneve. 2002. Plant propagation. Principles and practices. Vol. 849 p. $7^{\text {th }}$ ed. Prentice Hall, Upper Saddle River, New Jersey, USA.

Haslam, E., and T.H. Lilley. 1986. Polyphenol complexation. Groupe Polyphenols Bulletin de Liaison 13:352-357.

Herrero, J. 1951. Studies of compatible and incompatible graft combinations with special reference to hardy fruit trees. Journal of Horticultural Science 26:186-237.

Koepke, T., and A. Dhingra. 2013. Rootstock scion somatogenetic interactions in perennial composite plants. Plant Cell Report 32:1321-1337.

Kueger, S., D. Steinhauser, L. Willmitzer, and P. Giavalisco. 2012. High-resolution plant metabolomics: from mass spectral features to metabolites and from whole-cell analysis to subcellular metabolite distributions. The Plant Journal 70:39-50.

Lang, G.A., and D. Ophardt. 2000. Intensive crop regulation strategies in sweet cherries. Acta Horticulturae 514:227-234.

Lee, J.M., and M. Oda. 2003. Grafting of herbaceous vegetable and ornamental crops. Horticultural Reviews 28:61-124.

Leonardi, C., and D. Romano. 2004. Recent issues on vegetable grafting. Acta Horticulturae 631:163-174.

Long, L.E., and C. Kaiser. 2010. Sweet cherry rootstocks. Pacific Northwest Extension 619:8.

Martínez-Ballesta, M.C., C. Alcaraz-López, B. Muries, C. MotaCadenas, and M. Carvajal. 2010. Physiological aspects of rootstock-scion interactions. Scientia Horticulturae 127:112-118.
Mattsson, J., W. Ckurshumova, and T. Berleth. 2003. Auxin signaling in Arabidopsis leaf vascular development. Plant Physiology 131:1327-1339.

Moing, A., F. Carbonne, and J.P. Gaudillère. 1990. Growth and carbon partitioning in compatible and incompatible peach/plum grafts. Physiologia Plantarum 79:540-546.

Moing, A., and J.P. Carde. 1988. Growth, cambial activity and phloem structure in compatible and incompatible peach/plum grafts. Tree Physiology 4:347-359.

Mosse, B. 1962. Graft-incompatibility in fruit trees. Community Bureau of Horticultural East Malling Research 28:36.

Okie, W.R. 1987. Plum rootstocks. p. 321-360. In R.F. Carlson (ed.) Rootstocks for fruit crops. Wiley, New York, USA.

Olmstead, M.A., N.S. Lang, G.A. Lang, F.W. Ewers, and S.A. Owens. 2006. Examining the vascular pathway of sweet cherries grafted onto dwarfing rootstocks. American Society for Horticultural Science 41:674-679.

Parham, R.A., and H.M. Kaustinen. 1977. On the site of tannin synthesis in the plant cells. Botanical Gazzette 138:465-467.

Pina, A., and P. Errea. 2005. A review of new advances in mechanism of graft compatibility-incompatibility. Scientia Horticulturae 106:1-11.

Pina, A., and P. Errea. 2008. Differential induction of phenylalanine ammonia-lyase gene expression in response to in vitro callus unions of Prunus spp. Journal of Plant Physiology 165:705-714.

Pina, A., T. Zhebentyayeva, P. Errea, and A. Abbott. 2011. Isolation and molecular characterization of cinnamate 4-hydroxylase from apricot and plum. Biologia Plantarum 56(3):441-450.

Poëssel, J.L., J. Martinez, J.J. Macheix, et R. Jonard. 1980. Variations saisonnières de l'aptitude au greffage in vitro de Pêcher. Relations avec les tenuers en composès phènoliques endogènes et les activitiès peroxidasique et polyphenoloxydasique. Physiologie Vegetale 18:665-675.

Rogers, L.A., and M.M. Campbell. 2004. The genetic control of lignin deposition during plant growth and development. New Phytologist 164:17-30.

Rom, R.C., and R.F. Carlson. 1987. Rootstocks for fruit crops. Wiley, New York, USA.

Salesses, G., and A. Bonnet. 1992. Some physiological and genetic aspects of peach/plum graft incompatibility. Acta Horticulturae 315:177-186.

Salvatierra, M.A., H. Gemma, and S. Iwahori. 1998. Partitioning of carbohydrates and development of tissues in the graft union of peaches grafted on Prunus tomentosa Thunb. rootstock. Journal of the Japanese Society for Horticultural Science 67:475-482.

Salvatierra, M.A., H. Gemma, and S. Iwahori. 1999. Histochemical observation and HPLC analysis of phenolic compounds at the graft union of dwarf peach trees grafted onto Prunus tomentosa. Journal of Japanese Society for Horticultural Science 68:724-733.

Shimomura, T., and K. Fujihara. 1977. Physiological study of graft union formation in Cactus. II. Role of auxin on vascular connection between stock and scion. International Japanese. Society of Horticultural Science 45:397-406.

Sorce, C., R. Massai, P. Picciarelli, and R. Lorenzi. 2002. Hormonal relationships in xylem sap of grafted and ungrafted Prunus rootstocks. Scientia Horticulturae 93:333-342.

Stafford, H.A. 1990. Flavonoid metabolism. CRC Press, Boca Raton, Florida, USA.

Tiedemann, R. 1989. Graft union development and symplastic phloem contact in the heterograft Cucumis sativus on Cucurbita ficifolia. Journal of Plant Physiology 134:427-440.

Torel, J., J. Cillard, and P. Cillard. 1986. Antioxidant activity of flavonoids and reactivity with peroxy radical. Phytochemistry 25:383-385.

Treutter, D., and W. Feucht. 1988. Accumulation of the flavonoids prunin in Prunus avium/P. cerasus grafts and its possible involvement in the process of incompatibility. Acta Horticulturae 227:74-77.

Treutter, D., and W. Feucht. 1991. Accumulation of phenolic compounds above the graft union of cherry trees. Gartenbauwissenschaft 56:134-137. 
Usenik, V., B. Krška, M. Vičan, and F. Štampar. 2006. Early detection of graft incompatibility in apricot (Prunus armeniaca L.) using phenol analyses. Scientia Horticulturae 109:332-338.

Yeoman, M.M. 1984. Cellular recognition systems in grafting. p. 453-472. In Linkskens, H.F., I. Heslop-Harrison (eds.) Cellular interaction, encyclopaedia of plant physiology. New Series. Springer-Verlag, Berlin, Germany.

Yin, H., B. Yan, J. Sun, P. Jia, Z. Zhang, X. Yan, et al. 2012 Graft-union development: a delicate process that involves cellcell communication between scion and stock for local auxin accumulation. Journal of Experimental Botany 63:4219-4232.
Zaiger, C.F. 1982. Interspecific rootstock tree 4-G-816. In Patent A01H 5/03, USA. p. 3.

Zarrouk, O., Y. Gogorcena, M.A. Moreno, and J. Pinochet. 2006. Graft compatibility between peach cultivars and Prunus rootstocks. American Society for Horticultural Science 41:1389-1394. 